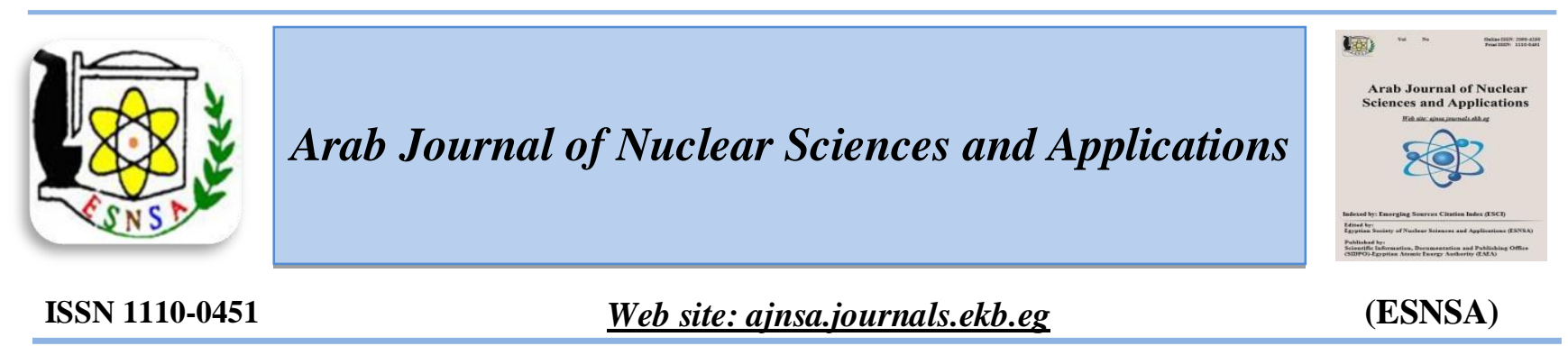

\title{
Formation of Porous Nanostructure Cobalt Oxide Electrodeposits on Stainless Steel 304 Surface Used as Solar Absorber
}

\author{
A. M. Raslan ${ }^{(1)}$, M. Nabiel ${ }^{(1)}$, Randa A. Kerem $^{(1)}$, A. F. Waheed ${ }^{(2)}$ \\ ${ }^{(1)}$ Metallurgy Department, Faculty of Engineering, Cairo University, Giza, Egypt \\ ${ }^{(2)}$ Materials Division, Metallurgy Department, Nuclear Research Center,Atomic Energy Authority, Cairo, Egypt
}

Received $2^{\text {th }}$ Nov. 2018 Cobalt oxide layers was formed on a stainless steel type 304 surface after annealing heat treatment (400 Accepted $8^{\text {th }}$ May 2019 oC / 10 hr) of the previously electrodeposited pure cobalt coating. The influence of heat treatment on surface morphology of pure cobalt films deposited has been studied. Crystallite structure transformation from hexagonal system to cubic system occurs. The coating layer morphology change from nano platelets to nano flecks was observed. SEM and EDAX are used for monitoring the gradually changes in the coated surface and nanostructure formation behavior. The degree of crystallinitey and crystallite size changes, due to annealing at 400 oC/10 hrs, were measured by XRD device. The optical properties were investigated using UV-IR Spectrometry to study the effect of the formed surface coating at different electrodeposition conditions on the solar energy absorption behavior. The optimal solar absorptance was found to be $98 \%$ at visible light wavelength range $(400-750 \mathrm{~nm})$ for the films after annealing heat treatment.

Keywords: Cobalt oxide layers, degree of crystallinitey, annealing heat treatment.

\section{Introduction}

In recent years the investigation of different ways to control the structure and morphology of deposited films has attracted a great deal of attention from the scientific community. The reason behind this is on one hand, the connection between material properties and the morphology, and on the other hand the assembled structure. [1] The physical and chemical properties of metal nanostructures were influenced by size and morphology. This has generated a considerable interest towards the development of techniques for the morphology-controlled synthesis of metal nanostructures. In numerous applications including, for example, electro-catalysis, the immobilization of metal nanostructures on a target substrate is required. Electrodeposition then becomes a competitive technological route to synthesize metal nanostructures.[2]

The application of cobalt nanostructure materials has attracted interest in numerous technological areas including, for example, the production of chemical sensors, high performance cathodes for alkaline hybrid batteries, and catalysts for water splitting and hydrogen evolution reactions. In any application, the achieved performances are largely influenced by the morphology of the cobalt nanostructures. Nanostructure morphology can, for example, affect the electrochemical efficiency of super capacitors and dictate the mechanism and the rate of electro-catalyzed reactions.[3]

The preparation aspects of cobalt oxide thin films have been a subject of investigations by various workers because of their numerous applications in various fields of technology. They are attractive in application to solar thermal energy collectors as selective absorbing layers. McDonald [4] reported that the black cobalt coating is formed by cobalt (II) oxide when it is electrodeposited from a Wattstype electrolytic bath containing hydrogen peroxide, although he did not describe the electrocrystallization mechanisms for this compound.

Corresponding author: ahraslan@gmail.com

DOI: 10.21608 /ajnsa.2019.5690.1142

(C) Scientific Information, Documentation and Publishing Office (SIDPO)-EAEA 
Smith et al. [5] prepared black cobalt using various procedures. One of their better results was achieved in a two-step process where the white metallic cobalt was first deposited on a nickel substrate and then converted to black cobalt through chemical oxidation (in an ammonium per sulfate medium). Once again, however, no details of the process were included. Hutchins et al. [6] also prepared black cobalt using different techniques, one of which involved electrodeposition of white cobalt. Once prepared, the white cobalt film was activated in nitric acid aqueous solution to form cobalt nitrate, which, as they attested, facilitated the cobalt oxide or hydroxide formation under a strong alkaline medium (ammonium persulfate). E. Barrera al. $[7,8,9]$ investigate the deposition mechanism of cobalt onto stainless steel with the presence of nitrates in Watts type solution. They found nitrates to be an essential component for direct cobalt electrodeposition, producing black cobalt. For all the previous researches the role of thermal treatment was as a thermal stability test for the deposited layer or used as an oxidation method for it.

In this work, selective surface based on nanocrystalline cobalt oxide film was prepared by annealing heat treatment of pure cobalt plated by direct electrodeposition. Applying of different deposition times and current densities, on stainless steel 304 substrates. The influence of thermal treatment (annealing at $400{ }^{\circ} \mathrm{C}$ for 10 hours) used for achieving crystal structure transformation. The objective of the present work consists in developing an experimental methodology to determine the effect of thermal treatment on the surface crystalline morphology change and formation of porous structure. Also, study the change on the roughness and optical properties of the selective surface produced.

\section{Experimental Work}

Substrate Preparation

The substrates were stainless steel plates of $20 \mathrm{~mm}$ Width $\times 45 \mathrm{~mm}$ length $\times 1.25 \mathrm{~mm}$ thickness. Surface area was embedded in an epoxy resin in such a way that only one phase was exposed to the solution. The cleaning process was consists of two steps; the first is direct cleaning the surface using acetone, and the second, ultrasonic cleaning for 5 minutes with immersion in ethanol. Activation of cleaned surface was done by immersing it in $10 \%$ diluted $\mathrm{HCl}$ solution for 2 minutes, then washing by double distilled water (DDW).

\section{Electrodeposition Process}

The Composition of the electrolytic solution is presented in Table (1). All solutions were prepared with ultrapure analytical grade reagents, and double distilled water. Experiments were carried out at room temperature in a conventional threeelectrode cell. As a working electrode (substrate for cobalt deposition), a stainless steel (type 304) with a $9.0 \mathrm{~cm}^{2}$ surface area used as working electrode. A platinum sheet with an $8.0 \mathrm{~cm}^{2}$ surface area was utilized as the counter electrode and a saturated calomel electrode (SCE) as the reference electrode. The electrodeposition experimental conditions can be summarized in Table (2).

Table (1): Chemical composition of the aqueous electrolytic bath

\begin{tabular}{cc}
\hline Chemical Compound & $\begin{array}{c}\text { Concentration } \\
(\text { gm / / ) }\end{array}$ \\
\hline Cobalt Sulfate $\left[\mathrm{CoSo}_{4}-7 \mathrm{H}_{2} \mathrm{O}\right]$ & 270 \\
Cobalt Chloride $\left[\mathrm{CoCl}_{2}-6 \mathrm{H}_{2} \mathrm{O}\right]$ & 35 \\
Cobalt Nitrate $\left[\mathrm{Co}\left(\mathrm{No}_{3}\right)_{2}-6 \mathrm{H}_{2} \mathrm{O}\right]$ & 2.5 \\
Boric Acid $\left[\mathrm{H}_{3} \mathrm{Bo}_{3}\right]$ & 30
\end{tabular}

Table (2): Electrodeposition process working parameters

\begin{tabular}{cc}
\hline Parameter & Value \\
\hline $\mathrm{pH}$ & 3.5 \\
Current Density $\left[\mathrm{mA} / \mathrm{cm}^{2}\right]$ & 20,30 and 40 \\
Temperature $[\mathrm{Co}]$ & Room Temp. \\
Deposition Time $[\mathrm{min}]$ & $1,2,3,4,5$ and 6 \\
\hline
\end{tabular}

\section{Thermal Treatment}

The oxidation of deposited pure cobalt films recently obtained were subjected to a annealing heat treatment, that consisted of the introduction of several samples in a stove with temperature control at $400^{\circ} \mathrm{C}$ for $10 \mathrm{~h}$ holding time interval.

\section{Metallic Cobalt and cobalt oxide films characterization}

Surface characterization of the cobalt metal and oxide coating was obtained by X-ray diffraction (XRD) using Analytical X'Pert PRO Materials Research Diffractometer, Holland made. A 4-circle diffractometer with various pre-aligned fast interchangeable $\mathrm{x}$-ray (PREFIX) optical modules 
for point- and line-focus applications. The X-ray tube with $\mathrm{Cu}$ anode gives $\mathrm{K}$-alpha radiation and is typically operated at $45 \mathrm{kV}$ (high-tension) and at 40mA (tube current). The open Eulerian geometry MRD cradle accepts wafers up to 4".

We used scanning electron microscopy (SEM) to observe the overall properties of the cobalt and cobalt oxide films. This study was carried out using a SEM Model Quanta 250 FEG (Field Emission Gun) attached with EDX Unit (Energy Dispersive X-ray Analyses), with accelerating voltage $30 \mathrm{~K} . \mathrm{V}$., magnification $14 \mathrm{x}$ up to 1000000 and resolution for Gun.1n). FEI Company, Netherlands.

The Surface Topography was measured by using 3D Image Analyzing Software [SCANDIUM Software]. Mitutoyo surface roughness measuring system, model SURFTEST.301, Japan, was used for surface layer roughness measurements. UVvisible-near IR spectrophotometer (JASCO-V-570) used in measurement the optical properties of cobalt metal and its oxide ions doped mayenite samples, Japan (integrating sphere reflectance unit).

\section{Results and Discussion}

Effect of electrodeposition parameters

For each current density of (20,30 and 40 $\mathrm{mA} / \mathrm{cm}^{2}$ ) applied to electrodeposition experiments, a holding time from $1 \mathrm{~min}$. to $9 \mathrm{~min}$. was used, through nine experiments for each current density. According to the XRD and SEM results for each experiment, the optimum holding time was found to be $6 \mathrm{~min}$. where, at times less than 6 minutes there is an observation about non complete coverage of deposited layer especially at lower current density $\left(20 \mathrm{~mA} / \mathrm{cm}^{2}\right)$. Based on the naked eye observation, for times above 6 minutes' peel off at the edges of the substrate were observed especially at higher current density $\left(40 \mathrm{~mA} / \mathrm{cm}^{2}\right)$ as shown in figure (1), because of brittle properties of deposit and the built-in high internal stress in the coating layer [10]. Therefore time of 6 minutes was selected as an optimum condition and as fixed factor to compare and study the properties of deposited layer among the other factors. The $\mathrm{pH}$ value of 3.5 was fixed for all electrodeposition experiments due to the composition of acidic salts used in the electrolytic bath as mentioned in table (1). Boric acid is a common additive found in nearly all aqueous transition metal plating solutions, yet its influence on metal nanostructure deposition.[11]
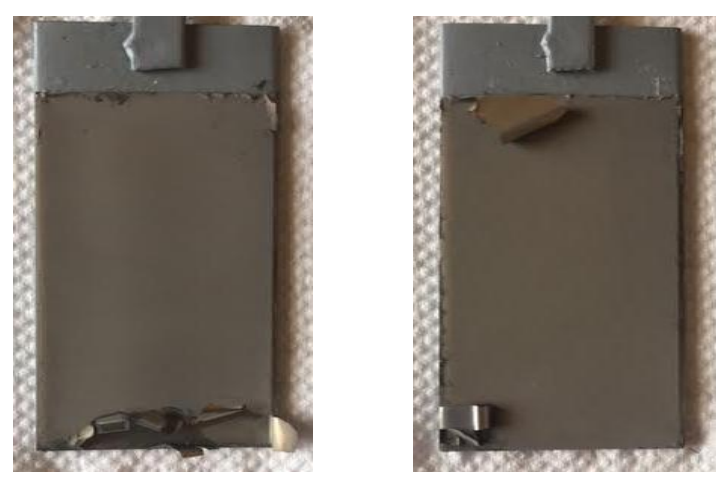

Figure (1): The Damage in surface layer by electrodeposition using times above 6 minutes at $\left(40 \mathrm{~mA} / \mathrm{cm}^{2}\right)$

The using of cobalt nitrate as an oxidizing agent improves the formation of black cobalt deposit according to the following faradaic (1 and 3) and chemical Reaction [2]. [12]

$\mathrm{Co}_{(\mathrm{aq})}{ }^{+2}\left(M_{.}\right)+2 \mathrm{e}^{-1} \leftrightarrow \mathrm{Co}_{(\mathrm{s})}[$ White Cobalt $]$ $2 \mathrm{H}_{(\mathrm{aq})}{ }^{+1}+\mathrm{NO}_{3(\mathrm{aq})}{ }^{-1}$
$\mathrm{NO}_{2(\mathrm{aq})}{ }^{-1}+\mathrm{H}_{2} \mathrm{O}$

Considering reaction [2], the authors propose simultaneous nitrate reduction during the cathodic process according to the following reaction;

$$
\begin{gathered}
2 \mathrm{H}_{(\mathrm{aq})}{ }^{+1}+\mathrm{NO}_{3(\mathrm{aq})}^{-1}+2 \mathrm{e}^{-1}(\mathrm{Co}) \leftrightarrow \mathrm{NO}_{2(\mathrm{aq})}^{-1}+ \\
\mathrm{H}_{2} \mathrm{O}_{(\mathrm{l})}
\end{gathered}
$$

And also a reduction to the oxidized cobalt ions during the cathodic process according to the following reaction;

$$
\mathrm{Co}_{(\mathrm{aq})}{ }^{+2}(O X .)+2 \mathrm{e}^{-1} \leftrightarrow \mathrm{Co}_{(\mathrm{s})} \quad[\text { Black Cobalt }]
$$

On the other hand, that consumption of the electrons cause an obvious decrease in the efficiency of the electrodeposition process as shown in figure (2). 


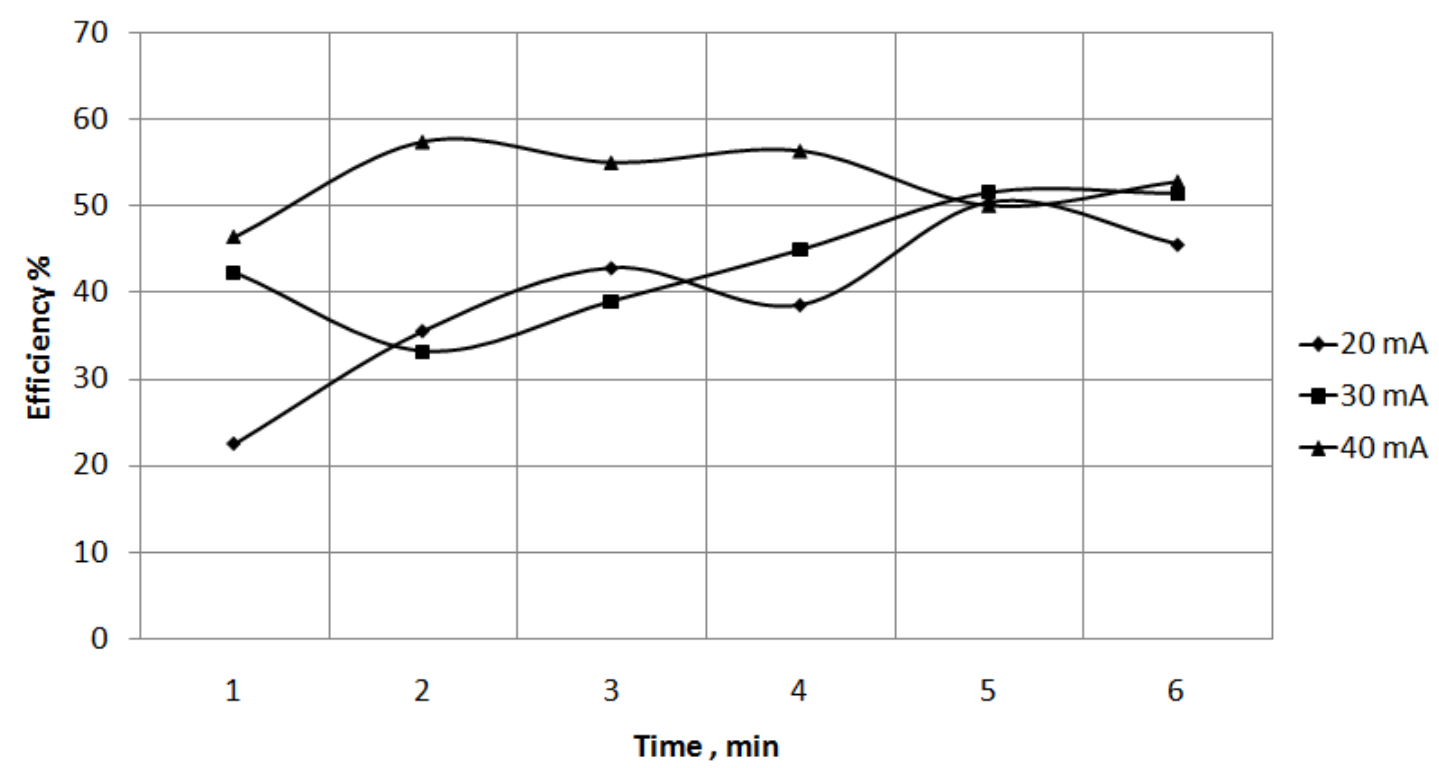

Figure (2): Efficiency diagram of the electrodeposition process at various conditions of deposition time and current density

The efficiency value at optimum deposition time (6 min.) has the lowest value at current density 20 $\mathrm{mA} / \mathrm{cm}^{2}$, as compared to the other current density values which is give an indication about the increasing in reaction density at this condition.

\section{XRD Characterization}

In order to identify the predominant cobalt phase in the deposited layer, it was necessary to investigate the deposit using X-ray diffractometer. The crystallite size $\mathbf{D}_{\text {hkl }}$ was calculated from the line broadening using the Scherer's equation: [13]

$$
D_{h k l}=\frac{k \cdot \lambda}{B_{h k l} \cdot \cos \theta}
$$

Where; $\lambda$ is the wavelength of the $\mathrm{CuK}_{\alpha}$ radiation $(1.54056 \times 10-10 \mathrm{~m}), \boldsymbol{\theta}$ the Bragg diffraction angle, $\boldsymbol{B}_{h k l}$ the full width at the half maximum intensity of the characteristic reflection peak $(2 \boldsymbol{\theta}=$ $36.86^{\circ}$ ), and $\boldsymbol{k}$ a constant (Usually $\boldsymbol{k}=0.94$ ).

In this study the authors classified the XRD analysis into two studies the first one at as deposited conditions and the second after the finish of the annealing thermal treatment. Figures (3), (4) and (5) presenting the X-ray diffraction patterns of the surface layers at various electrodeposition conditions. Pure cobalt was shown in patterns (a) at the left side, which are at as deposition conditions, and cobalt oxides was shown in patterns (b) at the right side, which are after annealing thermal treatment.
Figures (3-a), (4-a) and (5-a) presenting the XRD patterns for the as deposited pure cobalt at electrodeposition current densities 20,30 and 40 $\mathrm{mA} / \mathrm{cm}^{2}$ respectively, and other fixed process parameters. The higher intensity three peaks with miller indices (100), (002), and (101), which give characteristics for HCP pure cobalt crystal structure system properties as described in table (3). The behavior and direction of growth of the deposited pure cobalt is strongly affected by the changing in the current density value. Also the crystallite size is varying due to the same reason, all these effects were described in table (4). The highest intensity was observed at current density $\left(20 \mathrm{~mA} / \mathrm{cm}^{2}\right)$. Therefore, the strongly preferred orientation of pure cobalt is (002) at this condition and the growth orientation develops into this crystallographic direction. But, for the higher current densities (30 and $40 \mathrm{~mA} / \mathrm{cm}^{2}$ ) the strongly preferred orientation of pure cobalt is (100) at these condition and the growth orientation develops into this crystallographic direction.

Figures (3-b), (4-b) and (5-b) presenting the XRD patterns for the cobalt oxide $\left[\mathrm{Co}_{3} \mathrm{O}_{4}\right]$ after annealing treatment at electrodeposition current densities (20,30 and $\left.40 \mathrm{~mA} / \mathrm{cm}^{2}\right)$ respectively, and other fixed process parameters. The higher intensity peak with miller indices (311), gives characteristics for FCC cobalt oxide crystal structure system properties as described in table 
(3). The crystallite size is varying due to the changing in the current density value, as shown in table (4).

Therefore, the strongly preferred orientation of pure cobalt is (311) at this condition and the growth orientation develops into this crystallographic direction. It is worth mentioning that, the crystal size of cobalt oxide has the smallest value at current density $\left(20 \mathrm{~mA} / \mathrm{cm}^{2}\right)$, instead it was had the highest value of crystal size as a pure cobalt at the same current density, as observed from table (4).

\section{Scanning Electron Microscopy}

Figures (6), (7) and (8) shows the SEM of a stainless steel substrate covered with electrodeposited layer of pure cobalt as shown in images (a) at left side, which are at the as electrodeposition conditions, and cobalt oxide as shown in images (b) at right side, which are after annealing thermal treatment.

As shown figures (6-a), (7-a) and (8-a) the deposited film structure of pure cobalt at the as deposited conditions with applying current densities $\left(20,30\right.$ and $\left.40 \mathrm{~mA} / \mathrm{cm}^{2}\right)$ respectively. It can be seen that the deposited pure cobalt has compact and uniform surface morphology at micro scale revealing the uniformity of the deposition conditions i.e. deposit formation and growth during whole time of deposition. But it is obviously noticed that the internal nanostructure size increased with increasing the current density values. Thus, with further increase in the current density, the solution in the vicinity of the cathode tends to become depleted of metallic ions that had increased. Hence, the coated layer on the cathode surface is more compact.

High magnification image clearly revealed that the deposited layers have lumpy and uneven surface at all areas. From this observation, it is seen that sample morphology has composed of layered plates which look like flakes, with about $50-80$ nm thickness. Also, it seems that the most of flakes had vertical growth direction during deposition process on the cathode surface.

The role of annealing treatment as a thermal oxidation process for the as deposited pure cobalt can be observed by monitoring the oxygen content change as reported in table (5).

Table (3): Effect of electrodeposition parameters and annealing treatment on the crystal structure properties

\begin{tabular}{|c|c|c|c|}
\hline Property & As -Deposited & \multicolumn{2}{|c|}{ After Annealing } \\
\hline Morphology & $\begin{array}{c}\text { 3-D Nano } \\
\text { Platelets }\end{array}$ & \multicolumn{2}{|c|}{ 3-D Nano Flakes } \\
\hline Coating Phase & Metallic Cobalt & \multicolumn{2}{|c|}{ Cobalt Oxides $\left[\mathrm{CoO}, \mathrm{Co}_{3} \mathrm{O}_{4}\right]$} \\
\hline $\begin{array}{c}\text { Crystallographic } \\
\text { parameters }\end{array}$ & $\begin{array}{c}\text { Hexagonal } \\
\text { System } \\
\text { Co -metal } \\
\text { a }(\AA): 2.5060 \\
\text { b }(\AA): 2.5060 \\
\text { c }(\AA): 4.0690 \\
\text { Volume of cell } \\
\left(10^{\wedge} 6 \mathrm{pm}^{\wedge} 3\right): \\
22.13\end{array}$ & $\begin{array}{c}\mathrm{CoO} \\
\mathrm{a}(\AA): 4.2630 \\
\mathrm{~b}(\AA): 4.2630 \\
\mathrm{c}(\AA): 4.2630 \\
\text { Volume of cell }\left(10^{\wedge} 6\right. \\
\left.\mathrm{pm}^{\wedge} 3\right): \\
77.47\end{array}$ & $\begin{array}{c}\mathrm{Co}_{3} \mathrm{O}_{4} \\
\mathrm{a}(\AA): 8.1178 \\
\mathrm{~b}(\AA): 8.1178 \\
\mathrm{c}(\AA): 8.1178 \\
\text { Volume of cell }\left(10^{\wedge} 6\right. \\
\left.\mathrm{pm}^{\wedge} 3\right): \\
534.95\end{array}$ \\
\hline
\end{tabular}


Figures (6-b), (7-b) and (8-b) depict the surface morphology of black cobalt oxide films after annealing treatment. It is obvious that the crystal structure of black cobalt oxide film deposited shows a porous structure. The density and size of the formed pores is varying for different electrodeposition conditions. Even, the crystal structure morphology has been changed as it is seen from the figures, a thinning behavior occurred in the formed nano flakes that reach $10-40 \mathrm{~nm}$ thickness due to the crystal structure transformation from HCP system of the pure cobalt to FCC system of the cobalt oxide $\left(\mathrm{Co}_{3} \mathrm{O}_{4}\right)$, as a result of the annealing treatment, as mentioned in table (3). This form of morphology can provide the sample to have large surface area and pores, which can enable the prepared electro active material to exhibit better super thermal capacitive performance, to be used in solar absorption purposes.

Table (4) Effect of electrodeposition parameters and annealing treatment on the crystallite size measurements

\begin{tabular}{|c|c|c|c|c|}
\hline \multirow{3}{*}{$\begin{array}{l}\text { Electrodeposition } \\
\text { Conditions }\end{array}$} & \multicolumn{4}{|c|}{ Crystallite Size (nm) } \\
\hline & \multicolumn{3}{|c|}{$\begin{array}{l}\text { As Deposited } \\
\text { (Pure Cobalt) }\end{array}$} & \multirow{2}{*}{$\begin{array}{l}\text { After Annealing } \\
\left.\text { (Cobalt Oxide } \mathrm{Co}_{3} \mathrm{O}_{4}\right),[311]\end{array}$} \\
\hline & [100] & {$[002]$} & [101] & \\
\hline $20 \mathrm{~mA} / \mathrm{cm}^{2}, 6 \mathrm{~min}$. & 22.30 & 25.50 & 8.9 & 17.30 \\
\hline $30 \mathrm{~mA} / \mathrm{cm}^{2}, 6 \mathrm{~min}$. & 23.80 & 11.00 & 10.2 & 19.70 \\
\hline $40 \mathrm{~mA} / \mathrm{cm}^{2}, 6 \mathrm{~min}$. & 15.1 & 2.98 & 13.3 & 17.50 \\
\hline
\end{tabular}

Table (5): Effect of current density and annealing treatment on the surface layer composition. EDAX Analysis

\begin{tabular}{ccccc}
\hline \multirow{2}{*}{$\begin{array}{c}\text { Current } \\
\text { Density }\end{array}$} & \multicolumn{4}{c}{ Composition (at \%) } \\
\cline { 2 - 5 }$\left(\mathbf{m A} / \mathbf{c m}^{2}\right)$ & As Electrodeposition & \multicolumn{2}{c}{ After Annealing } \\
\cline { 2 - 5 } & $\mathbf{C o}$ & $\mathbf{O}_{\mathbf{2}}$ & $\mathbf{C o}$ & $\mathbf{O}_{\mathbf{2}}$ \\
\hline 20 & 83.60 & 5.22 & 60.24 & 20.85 \\
30 & 89.74 & 5.02 & 69.99 & 20.84 \\
40 & 89.43 & 4.94 & 77.74 & 18.11 \\
\hline
\end{tabular}

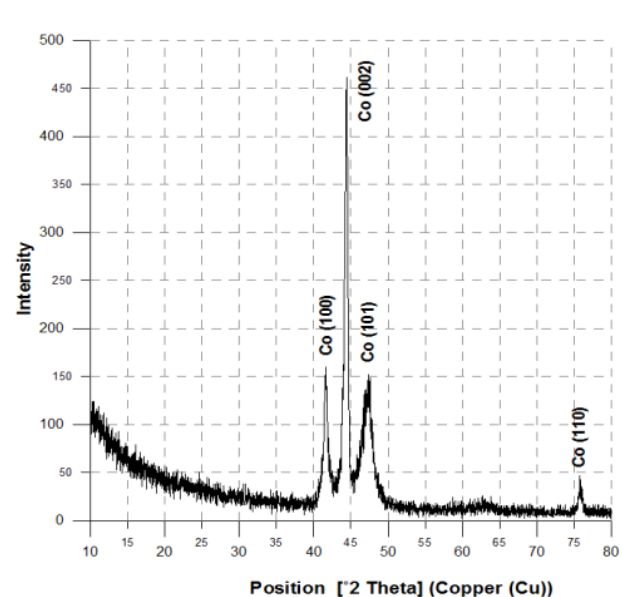

(a)

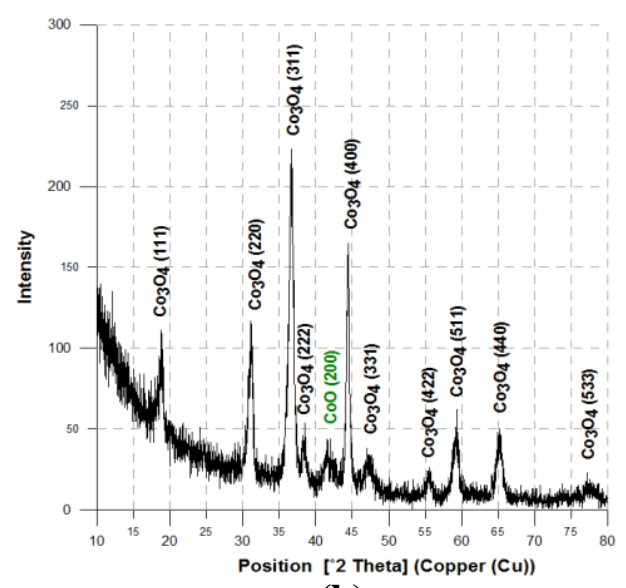

(b)

Figure (3): XRD of stainless steel surface covered with; (a) cobalt metal as deposited, (b) cobalt oxides after annealing $\left(400^{\circ} \mathrm{C} / 10 \mathrm{~h}\right)$. Electrodeposition conditions; current density $\left(20 \mathrm{~mA} / \mathrm{cm}^{2}\right)$, deposition time $(6 \mathrm{~min})$, bath composition as given in table (1). 


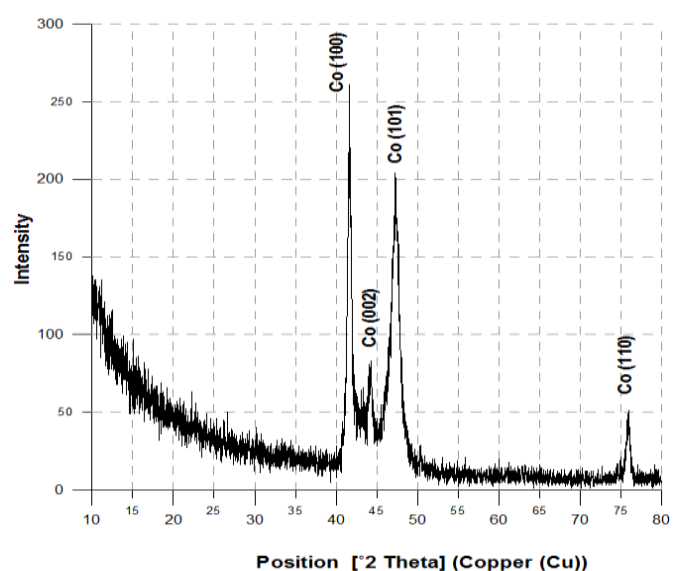

(a)

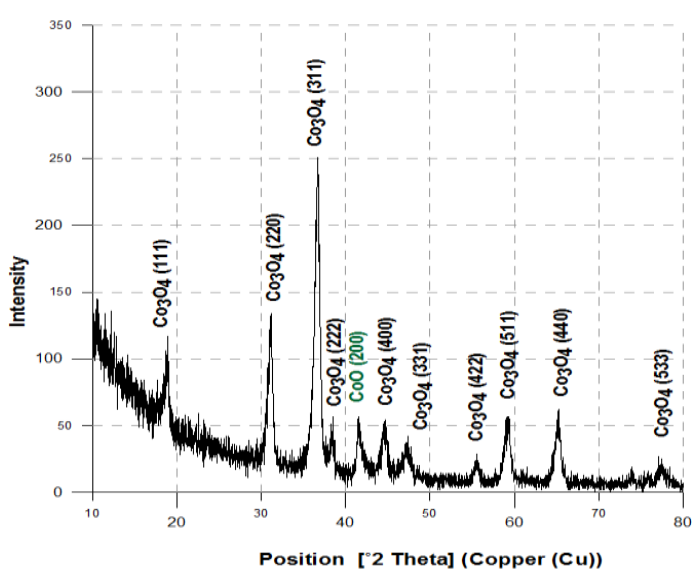

(b)

Figure(4): XRD of stainless steel surface covered with; (a) cobalt metal as deposited, (b) cobalt oxides after annealing $\left(400^{\circ} \mathrm{C} / 10 \mathrm{~h}\right)$. Electrodeposition conditions; current density $\left(30 \mathrm{~mA} / \mathrm{cm}^{2}\right)$, deposition time $(6 \mathrm{~min})$, bath composition as given in table (1).

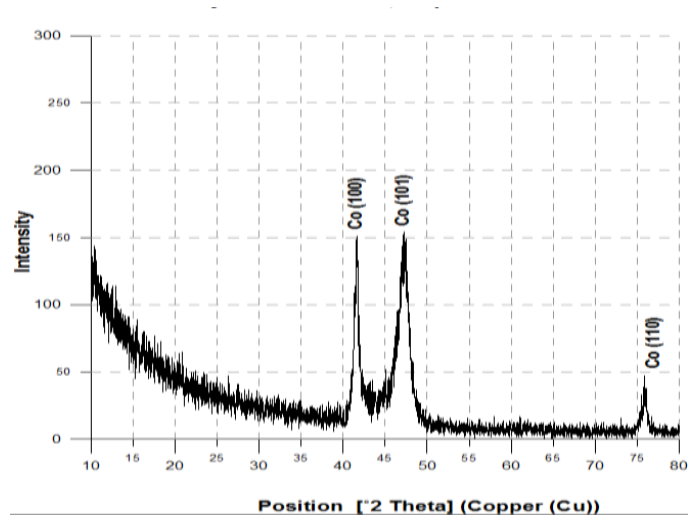

(a)

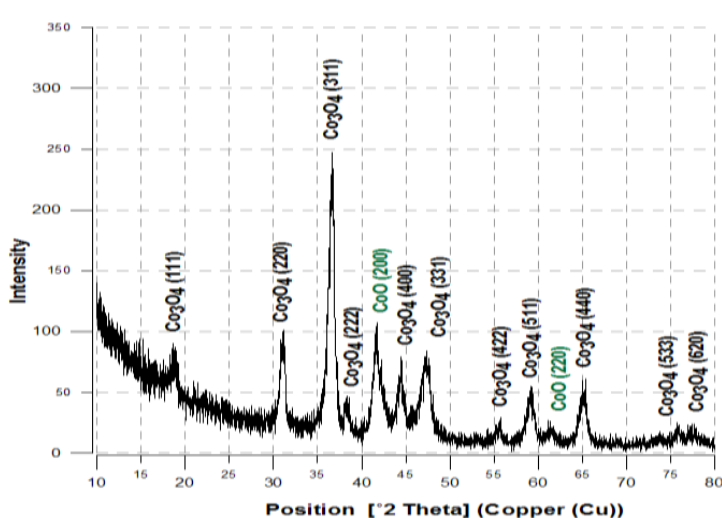

(b)

Figure(5): XRD of stainless steel surface covered with; (a) cobalt metal as deposited, (b) cobalt oxides after annealing $\left(400^{\circ} \mathrm{C} / 10 \mathrm{~h}\right)$. Electrodeposition conditions; current density $\left(40 \mathrm{~mA} / \mathrm{cm}^{2}\right)$, deposition time $(6 \mathrm{~min})$, bath composition as given in table (1).

Corresponding author: ahraslan@gmail.com

DOI: $10.21608 /$ ajnsa.2019.5690.1142

(C) Scientific Information, Documentation and Publishing Office (SIDPO)-EAEA 

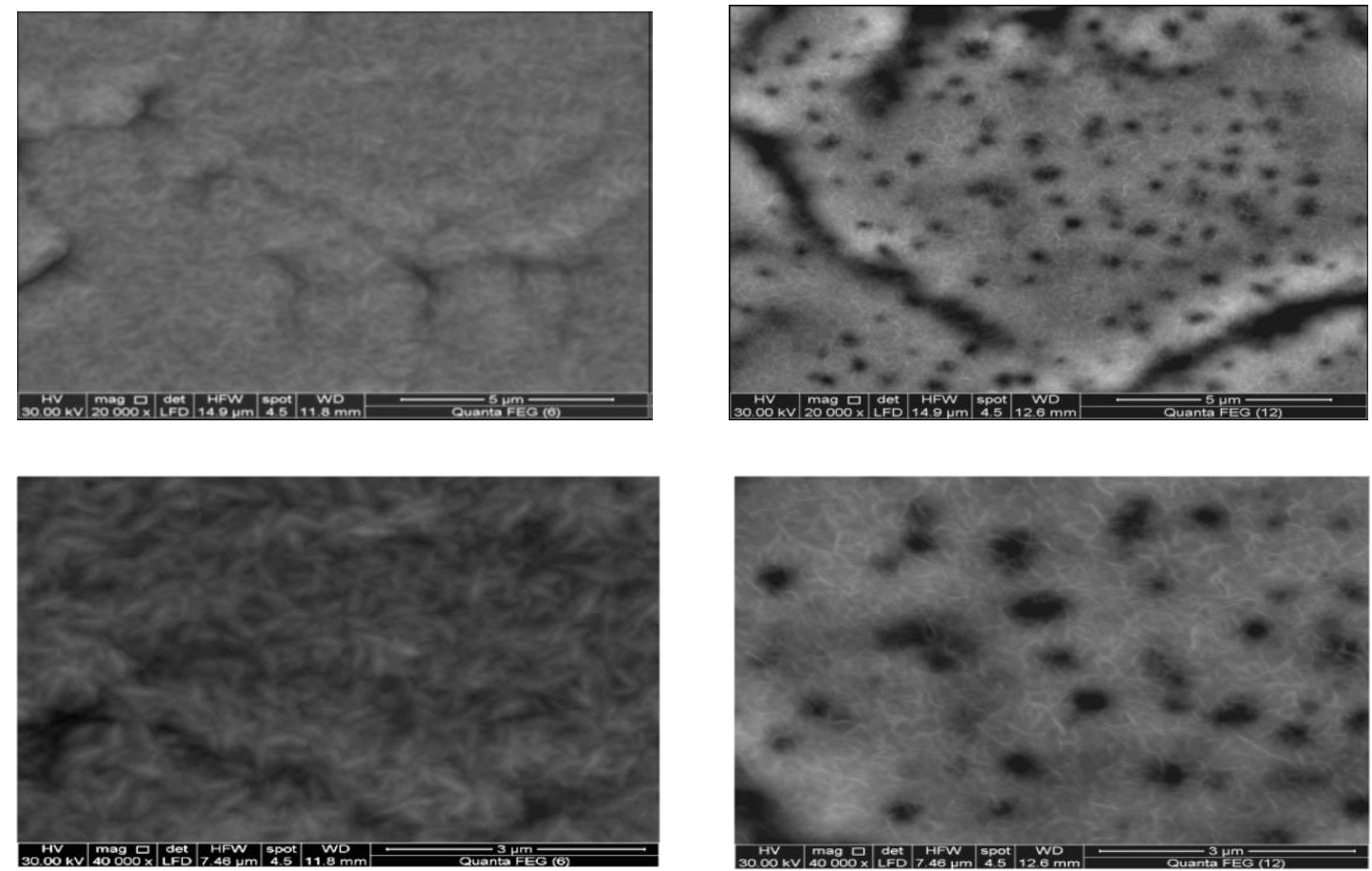

(a)

(b)

Figure (6): SEM of stainless steel surface covered with; (a) pure cobalt at as deposited, (b) cobalt oxides after annealing $\left(400^{\circ} \mathrm{C} / 10 \mathrm{~h}\right)$. Electrodeposition conditions; current density $\left(20 \mathrm{~mA} / \mathrm{cm}^{2}\right)$, deposition time $(6 \mathrm{~min})$, bath composition as given in table(1).
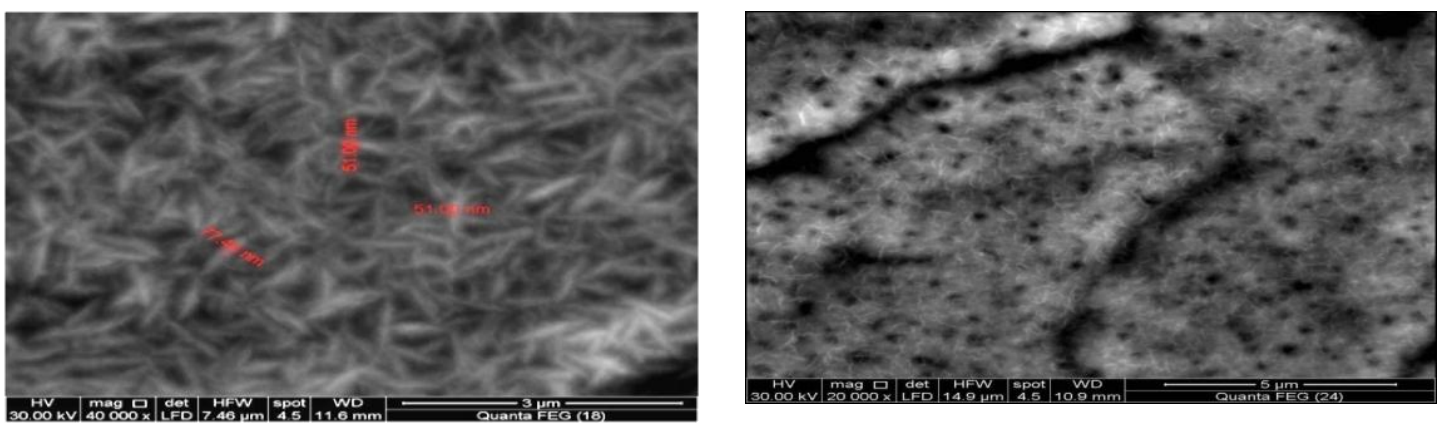

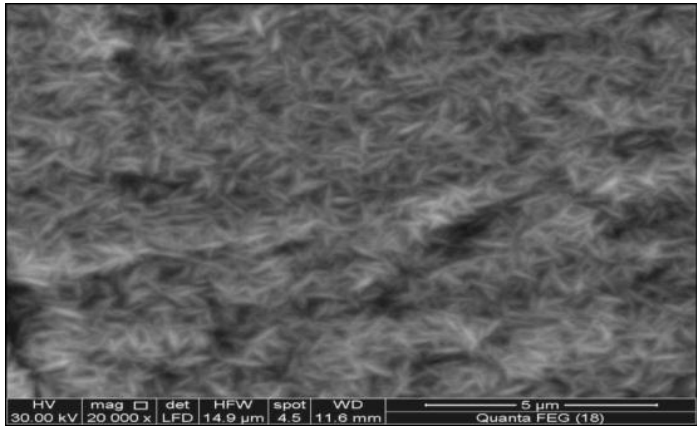

(a)

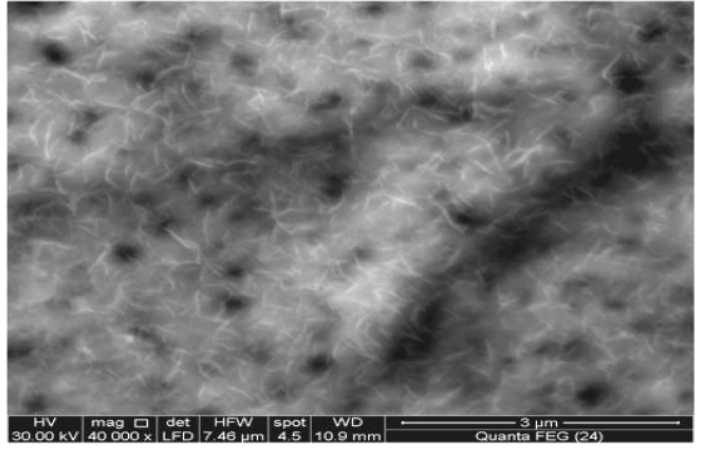

(b)

Figure (7): SEM of stainless steel surface covered with; (a) cobalt metal as deposited, (b) cobalt oxides after annealing $\left(400^{\circ} \mathrm{C} / 10 \mathrm{~h}\right)$. Electrodeposition conditions; current density $\left(30 \mathrm{~mA} / \mathrm{cm}^{2}\right)$, deposition time $(6 \mathrm{~min})$, bath composition as given in table (1). 

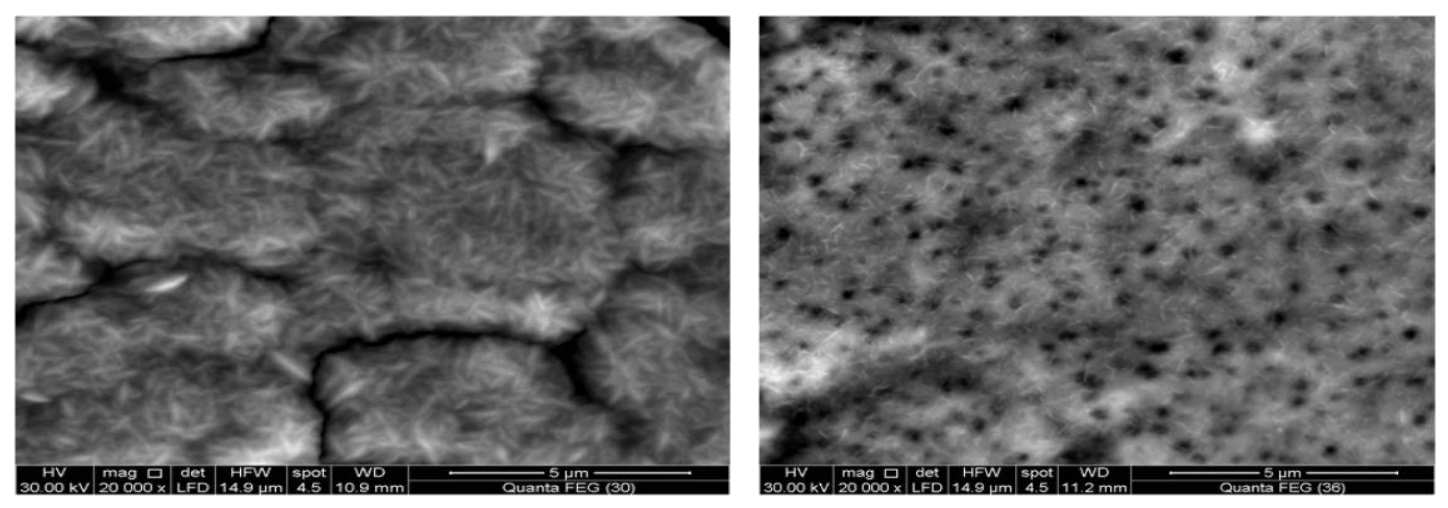

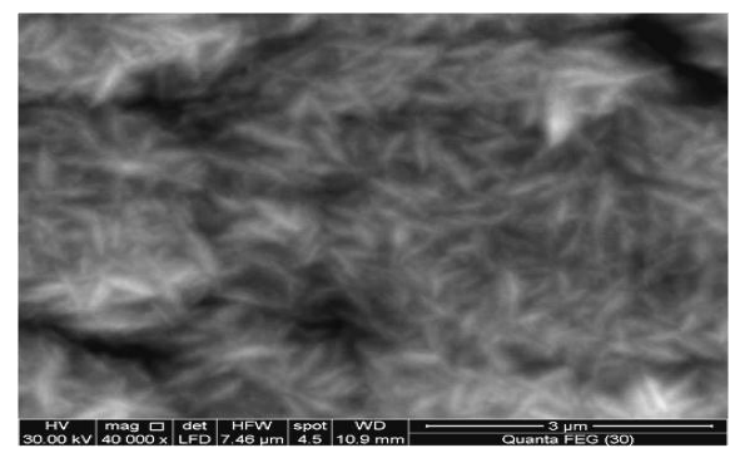

(a)

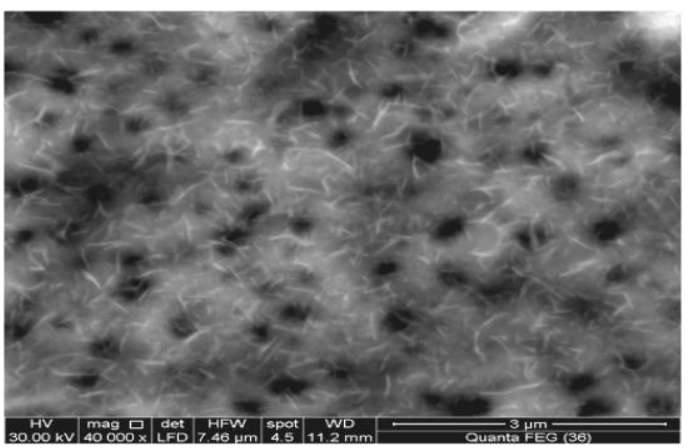

(b)

Figure (8): SEM of stainless steel surface covered with; (a) cobalt metal as deposited, (b) cobalt oxides after annealing $\left(400^{\circ} \mathrm{C} / 10 \mathrm{~h}\right)$. Electrodeposition conditions; current density $\left(40 \mathrm{~mA} / \mathrm{cm}^{2}\right)$, deposition time $(6 \mathrm{~min})$, bath composition as given in table (1).

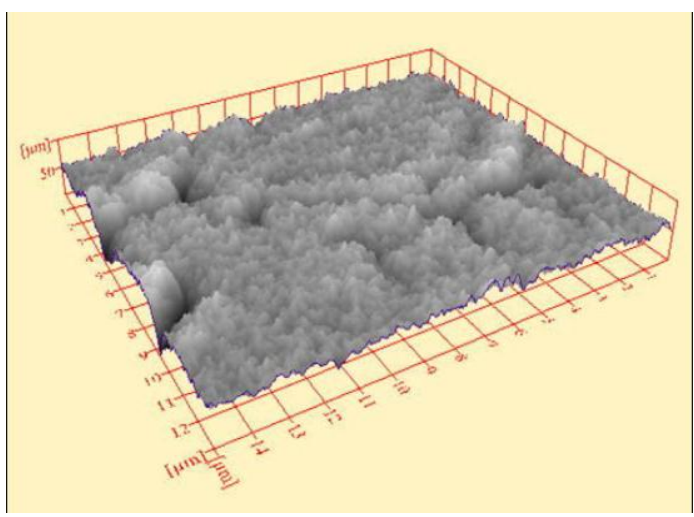

(a)

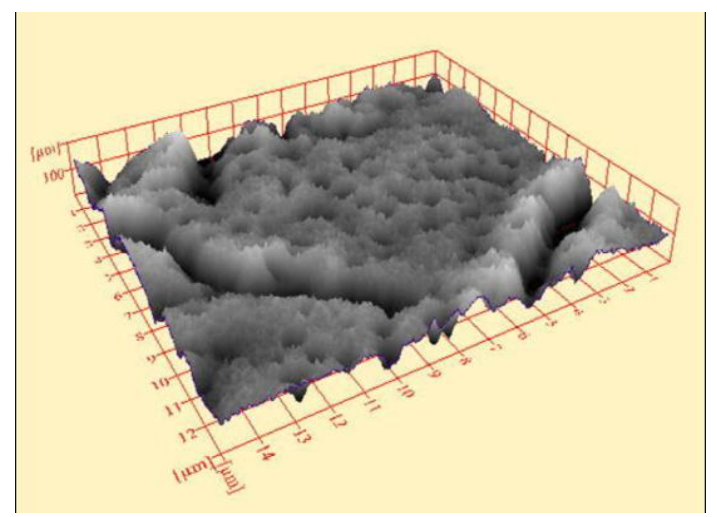

(b)

Figure (9): Surface topography of stainless steel surface covered with; (a) cobalt metal as deposited, (b) cobalt oxides after annealing $\left(400^{\circ} \mathrm{C} / 10 \mathrm{~h}\right)$. Electrodeposition conditions; $20 \mathrm{~mA} / \mathrm{cm}^{2}, 6 \mathrm{~min}$., bath composition as given in table (1) 


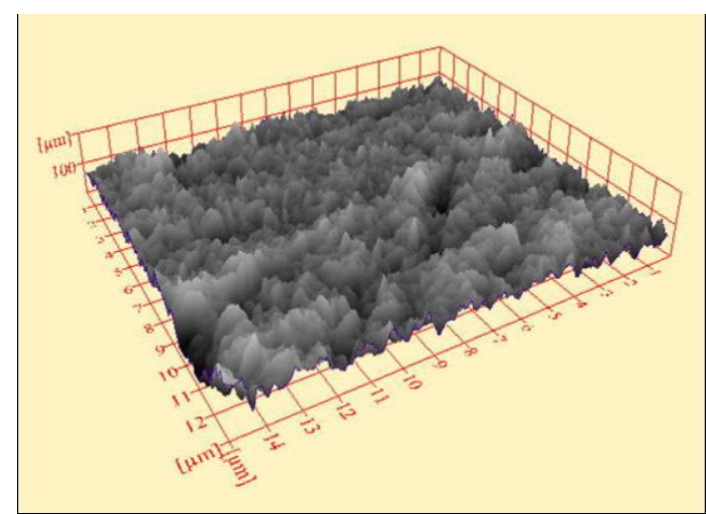

(a)

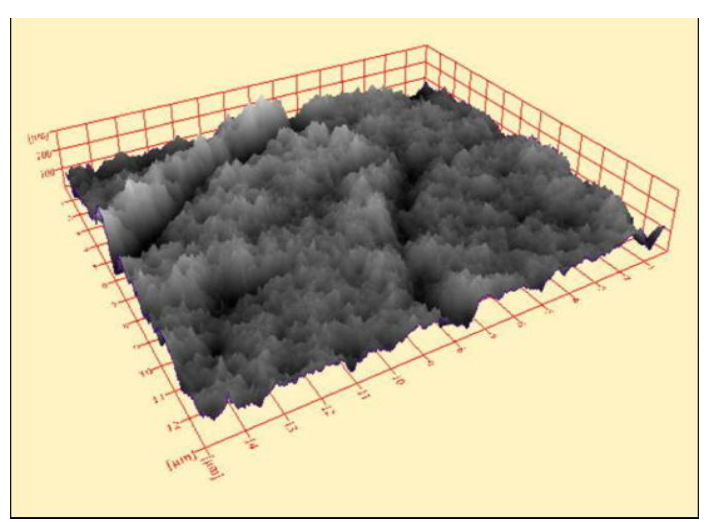

(b)

Figure (10) Surface topography of stainless steel surface covered with; (a) cobalt metal as deposited, (b) cobalt oxides after annealing $\left(400^{\circ} \mathrm{C} / 10 \mathrm{~h}\right)$. Electrodeposition conditions; $30 \mathrm{~mA} / \mathrm{cm}^{2}, 6 \mathrm{~min}$., bath composition as given in table (1)

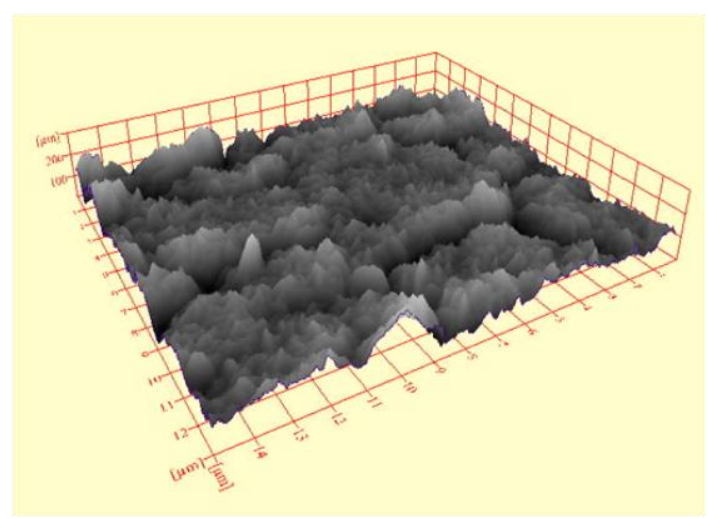

(a)

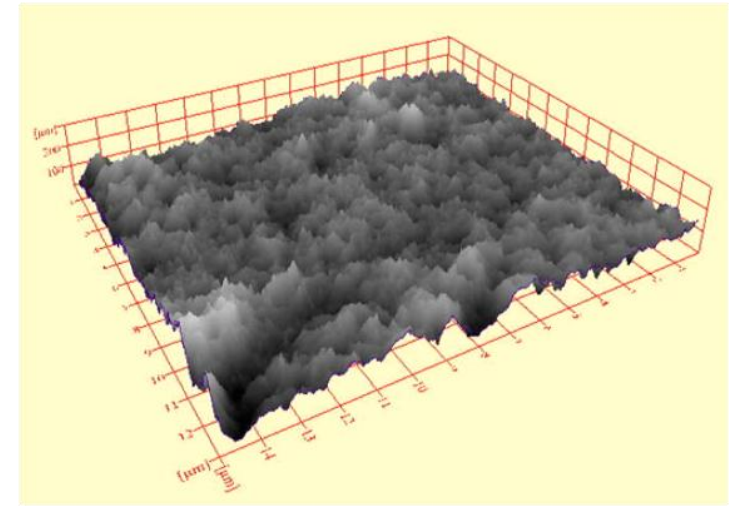

(b)

Figure (11): Surface topography of stainless steel surface covered with; (a) cobalt metal as deposited, (b) cobalt oxides after annealing $\left(400^{\circ} \mathrm{C} / 10 \mathrm{~h}\right)$. Electrodeposition conditions; $40 \mathrm{~mA} / \mathrm{cm}^{2}, 6 \mathrm{~min}$., bath composition as given in table (1)

\section{Optical Properties}

Absorption coefficient of the coating layers can be calculated according to Kirchhoff's law, which states that the sum of the absorptance, transmittance, and reflectance of the surface in particular wavelength equals to one. $[14,15]$

$\mathrm{A}+\mathrm{R}+\mathrm{T}=1$
Where $\mathrm{A}$ is absorptance, $\mathrm{T}$ is transmittance, and $\mathrm{R}$ is reflectance of surface. In the opaque surfaces where their transmittance is zero, it can be expressed as:

$\mathrm{A}+\mathrm{R}=1$ 


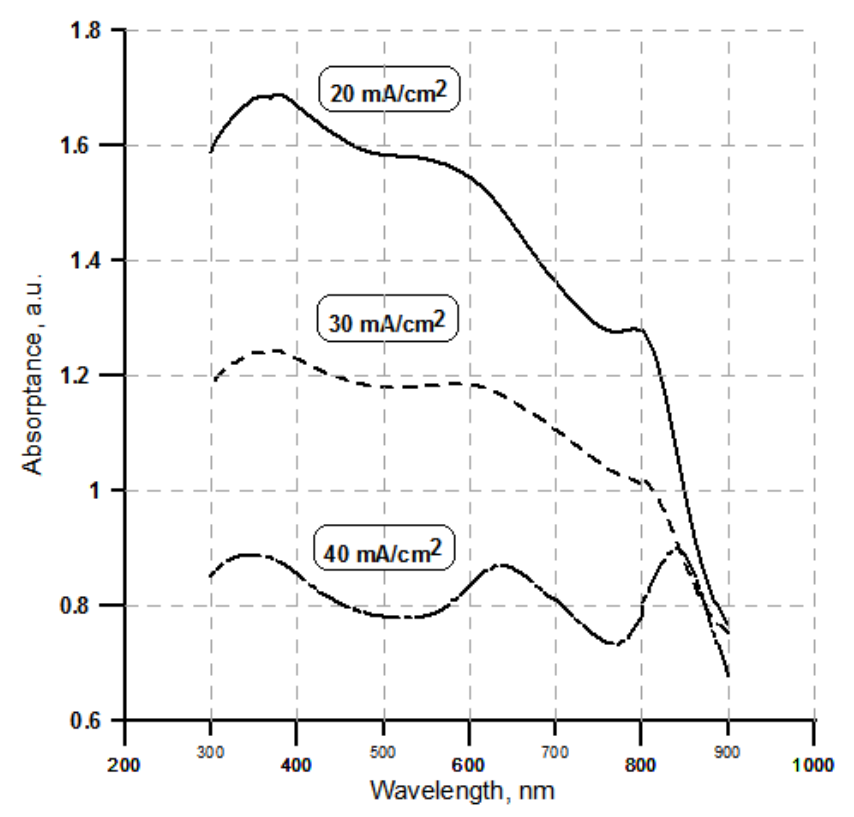

Figure (12): Effect of the current density on the absorptance behavior of cobalt oxide layer

Figure (12) is presenting the absorptance behavior by the wavelength of stainless steel 304 substrates covered with cobalt oxide films formed by annealing thermal treatment of electrodeposited pure cobalt layers within the use of different current density values. The optical properties were studied in the $300-900 \mathrm{~nm}$ region which including the visible light region $(400-750 \mathrm{~nm})$. As its obviously shown in the figure, the absorptance behavior was inversely proportional to the values of the current density. Where, the higher absorptance was achieved from the oxidation of pure cobalt which deposited by using $\left(20 \mathrm{~mA} / \mathrm{cm}^{2}\right)$ current density, and the lower absorptance value gained at $\left(40 \mathrm{~mA} / \mathrm{cm}^{2}\right)$ current density. But for all current density values, the absorption behavior has a sharp decrease near to the IR-region (over 800 $\mathrm{nm})$. The optimal solar absorptance was $98 \%$ at visible light wavelength range $(400-750 \mathrm{~nm})$ for the films after annealing heat treatment.

\section{Conclusions}

Black cobalt coatings (cobalt oxide $-\mathrm{Co}_{3} \mathrm{O}_{4}$ ) on stainless steel 304 substrate were prepared by applying annealing heat treatment to the pre electrodeposited pure cobalt layers. Heat treatment of pure cobalt films deposited on stainless steel 304 substrate caused crystal structure transformation into the deposited layer structure which leads to the formation of porous surface structure and nano flakes morphology. Heat treatment of pure cobalt deposited caused a sharp decrease in the absorption at near-IR region, whereas an excellent behavior was observed in the visible region. For the present electrodeposition process parameters, the current density in the electrodeposition process was considerd as an influential factor. Lower values of current density give the best structure after heat treatment to improve the absorptance behavior.

\section{References}

1-X. Yanpeng, A. Taleb and P. Jegoub, Electrodeposition of cobalt films with an oriented fir tree-like morphology with adjustable wetting properties using a self-assembled gold nanoparticle modified HOPG electrode, Journal of Materials Chemistry A, (2013), 1, 11580-11588.

2-R. Hallaj , K. Akhtari, A. Salimi, S. Soltanian, Controlling of morphology and electrocatalytic properties of cobalt oxide nanostructures prepared by potentiodynamic deposition method, Applied Surface Science 276 (2013) 512- 520.

3-3-P. G. Schiavi, P. Altimari, R. Zanoni, F. Pagnanelli, Morphology controlled synthesis of cobalt nanostructures by facile electrodeposition: transition from hexagonal nanoplatelets to nanoflakes, ElectrochimicaActa 220 (2016) 405-416.

4-G. McDONALD, a Preliminary study of a solar selective coating system using a black cobalt oxide for high temperature solar collectors, Thin. Solid Films, 72 (1980) 83-87. 
5-G. B. Smith, A. Ignatiev, and G. Zajac, Solar selective black cobalt: preparation, structure, and thermal stability , Journal of Applied Physics 51, 4186 (1980).

6-M.G. Hutchins, P.J. Wright and P.D. Grebenik, Comparison of different forms of black cobalt selective solar absorber surfaces, Solar Energy Materials 16 (1987) 113-131.

7-E. Barrera , I. Gonzals , T. Viveros , A new cobalt oxide electrodeposit bath for solar absorbers, Solar Energy Materials and Solar Cells 51 (1998) 69-82.

8-E. Barrera, M. P. Pardavé, N. Batina, and I. González, Formation Mechanisms and Characterization of Black and White Cobalt Electrodeposition onto Stainless Steel, Journal of The Electrochemical Society, 147 (5) 1787-1796 (2000).

9-C.E Barrera, L. Salgado, U. Morales, I. Gonza'1ez , Solar absorptance of black cobalt and black cobaltsilver films and its relation with roughness coefficient, Renewable Energy 24 (2001) 357-364.
10-Z. Abdel Hamid, A. Abdel Aal and P. Schmuki, Nanostructured black cobalt coatings for solar absorbers, Surface and Interface Analysis.(2008), 40, 1493-1499.

11-L. M. Graham, The effect of boric acid on the growth mechanism of electrodeposited metal nanostructures, Doctor of Philosophy (2014).

12-E. M. Garcia, V. Lins and T. Matencio, Metallic and Oxide Electrodeposition, Intech, Modern Surface Engineering Treatments, (2013)101 - 122.

13-I. KELPŠAITĖ ， J. BALTRUŠAITIS ， E. VALATKA, Electrochemical Deposition of Porous Cobalt Oxide Films on AISI 304 Type Steel, MATERIALS SCIENCE (MEDŽIAGOTYRA). Vol. 17, No. 3. (2011), 236 - 243.

14-S. P. Sakhatme, Solar Energy Principles of Thermal Collection and Storage, McGraw-Hill: New Delhi, (2001).

15-J. F. Kreider, F. Kreih, SolarEnergyHandbook,McGrawHill:NewYork, (1981). 